Vorteile des Verfahrens. 1. Nach einer einmaligen Zusammenstellung ist das Gefäß ununterbrochen zum Messen bereit. 2. Minimaler Quecksilberverbrauch zur Herstellung des Quecksilberbodens. 3. Einfache und schnelle Durchführung der Messungen. 4. Große Zeitersparnis.

Dipl.-Ing. Jaroslav Stabryn

Zentrallaboratorium in

Hrušovské chemické závody

Ostrava-Hrušov, CSSR

\section{Titrimetric Microdetermination of Zinc with EDTA Using 1,5-Di- $\beta$-Naphthylthiocarbazone (HNDZ) as an Extractive Indicator}

Titrimetrische Mikrobestimmung von Zink mit ÄDTA unter Verwendung von 1,5-Di- $\beta$-Naphthylthiocarbazon als Extraktionsindicator

\section{S. K. Strdemant and R. P. Singh}

Department of Chemistry, University of Delhi, Delhi-7, India

Received December 22, 1971

1,5-Di- $\beta$-naphthylthiocarbazone has been found to form a violet complex instantaneously with zinc, which is extractable in chloroform and carbon tetrachloride. The colour reaction is highly sensitive. Accurate results for the microdetermination of zinc are obtained in the $\mathrm{pH}$ range 3.80 to $4.50 . \mathrm{pH} 4.0$ has been selected for subsequent studies. One drop of indicator solution containing $5 \mathrm{mg}$ of HDNZ in $100 \mathrm{ml}$ of chloroform is sufficient to cause a sharp change of colour within a very short interval of time. A too large amount of the indicator results in a too dark colour.

The following diverse ions did not hinder the microdetermination of zinc when present in large excess: thiosulphate, borate, thiocyanate, chloride, bromide, iodide, tartrate, phosphate, sulphate, sulphite, chromate, fluoride, oxalate, manganese, calcium, barium, strontium, magnesium and copper (thiosulphate used as masking agent).

The accuracy and sensitivity proposed by the present method is very high as compared with dithizone (sensitivity being $0.0007 \mu \mathrm{g} \mathrm{Zn} / \mathrm{cm}^{2}$ ).

Recommended Procedure. Pipette $10 \mathrm{ml}$ of $1 \times 10^{-2} \mathrm{M}$ EDTA solution into a ground-glass flask, buffer to $\mathrm{pH} 4.0$ by means of ammonium acetate/acetic acid followed by the addition of one drop of indicator solution $(5 \mathrm{mg}$ per $100 \mathrm{ml}$ of chloro- form). Titrate with zinc solution $\left(1 \times 10^{-2} \mathrm{M}\right)$ taken from a microburette. Proceed slowly till the colour of the indicator turns from green to violet. Shaking is very necessary after each addition of zinc. In subsequent titrations the indicator solution is added just before the end point. From the titrimetric values the accuracy is determined by calculating percent error by the method of Ringbom [1].

Acknowledgement. One of the authors (SKS) is thankful to the Council of Scientific and Industrial Research for the appointment of Pool Officer.

\section{References}

1. Ringbom, E.: Complexation in analytical chemistry, pp. 77-81. New York: Intersci. Publ. 1963.

R. P. Singh

Department of Chemistry

University of Delhi

Delhi-7, India

\section{Precipitation of Chromium Oxinate from Homogeneous Solutions}

Fällung von Chromoxinat aus homogener Lösung

J. RAJAGopala RAO* and M. N. SASTRI

Department of Chemistry, Andhra University, Waltair, South India

Received November 8, 1971/Revised February 21, 1972

It is known that chromium and oxine form a complex of definite composition [1], but systematic investigation on the analytical applications of the complex does not seem to have been made so far. As the technique of precipitation from homogeneous solution is an improved method of gravimetric analysis and gives more reliable results, this technique has been employed in our experiments.

\section{Procedure for Precipitation of the Complex}

Preliminary investigations showed that chromium(III) can be quantitatively precipitated as its oxinate complex by following any of the four homogeneous precipitation procedures given below:

a) Precipitation by Urea Hydrolysis [3] ${ }^{1}$. The solutions containing about $10 \mathrm{mg}$ of chromium(III), $8 \mathrm{mI}$ of $2 \%$ oxine

* Present address: Regional Research Laboratory, Bhubaneswar, India.

1 Before we could communicate the results of our investigations [4], a method for the precipitation of chromium. oxinate by the urea hydrolysis method was reported [3]. The procedure was included in the present communication as some more studies were made on the precipitate obtained by following this procedure. 